\title{
PENGARUH TERAPI DIAPHRAGMATIC BREATHING EXERCISE TERHADAP PENGONTROLAN PERNAPASAN PASIEN ASMA DI KECAMATAN SRUWENG
}

\author{
Bambang Utoyo, Irmawan Andri Nugroho \\ Sekolah Tinggi Ilmu Kesehatan Muhammadiyah Gombong, \\ *e-mail: mamas.bambang@gmail.com
}

\begin{tabular}{|c|c|}
\hline & Abstract \\
\hline $\begin{array}{l}\text { Keywords: } \\
\text { diaphragmatic } \\
\text { breathing } \\
\text { exercise, } \\
\text { pengontrolan } \\
\text { pernapasan, } \\
\text { asma }\end{array}$ & $\begin{array}{l}\text { Salah satu intervensi pada pasien asma yang diterapkan untuk } \\
\text { meningkatkan otot-otot pada system pernapasan untuk memaksimalkan } \\
\text { ventilasi paru yaitu dengan Terapi Diafragmatic Breathing Exercise. } \\
\text { Tujuan penelitian ini adalah mengetahui pengaruh terapi diaphragmatic } \\
\text { breathing exercise terhadap pengontrolan pernapasan pasien asma di } \\
\text { Kecamatan Sruweng. Penelitian ini menggunakan desain quasi } \\
\text { experiment dengan pendekatan pre-test-post-test with control two group } \\
\text { design. Populasi dalam penelitian ini adalah } 42 \text { pasien asma. Sampel } 32 \\
\text { pasien yang diambil secara accidental sampling. Data dianalisa secara } \\
\text { deskriptif dan komparatif menggunakan uji t-test. Hasil penelitian } \\
\text { menunjukkan terdapat pengaruh terapi diaphragmatic breathing exercise } \\
\text { terhadap pengontrolan pernapasan pasien asma di Kecamatan Sruweng. } \\
\text { p value: 0,000 (p <0.05). Kesimpulan penelitian ini yaitu terapi } \\
\text { diaphragmatic breathing exercise efektif meningkatkan pengontrolan } \\
\text { pernapasan pasien asma. Rekomendasi penelitain ini diharapkan kepada } \\
\text { pelayanan kesehatan untuk menjadikan hasil penelitian ini sebagai } \\
\text { evidence base dalam praktik keperawatan. Hasil penelitian dapat } \\
\text { dijadikan masukan dalam menentukan kebijakan dan dasar penyusunan } \\
\text { standar operasional prosedur (SOP) diaphragmatic breathing exercise } \\
\text { pada pasien asma. }\end{array}$ \\
\hline
\end{tabular}

\section{PENDAHULUAN}

Menurut World Health Organisation (WHO, 2013) dilaporkan penyakit asma akhir-akhir ini kejadiannya mengalami peningkatan yang sangat tinggi dengan banyaknya mortalitas dan morbiditas. WHO setiap tahunnya diperkirakan 100-150 juta penduduk didunia mengalami penambahan jumlah hingga 180.000. Diperkirakan orang yang terkena asma diseluruh dunia mencapai 235 juta penderita asma serta penyebab kematian paling banyak pada Negara berkembang dan Negara miskin. Prevalensi asma pada tahun 2013 mengalami peningkatan sebesar 367 kasus. Pada tahun 2014 pasien asma meningkat sebesar 428 kasus. Setiap tahunnya pasien asma yang meninggal dari seluruh dunia hingga 250.000. Prevalensi pasien yang mengalami asma pada tahun 2015 sekarang ini meningkat menjadi 500 kasus (WHO, 2017).

Di Indonesia penyakit asma masuk dalam sepuluh besar penyakit penyebab kematian. Prevalensi asma di Indonesia mencapai $4,5 \%$ dengan jumlah penderita 
terbanyak oleh perempuan sebanyak 4,6\% serta laki-laki sejumlah 4,4\% (Kemenkes RI, 2014). Prevalensi penyakit asma pada penduduk semua usia di Indonesia dari tahun 2013 hingga 2018 mencapai 4,5\% (46.335 orang) dari $93 \%$ (1.027.763) (RISKESDAS, 2018). Berdasarkan Dinas Kesehatan (DINKES) penderita asma di Jawa Tengah tahun 2013 ada 113.028. Prevalensi penyakit asma pada penduduk semua usia di Indonesia dari tahun 2013 hingga 2018 mencapai 4,5\% (46.335 orang) dari $93 \quad \% \quad(1.027 .763)$ (RISKESDAS, 2018). Kasus serta jumlah penyakit asma tertinggi ada di Surakarta ada 10.393 kasus (Dinkes Jawa Tengah, 2013). (Dinkes, Surakarta, 2015) dari hasil studi pendahuluan yang dilakukan pada tanggal 06 Juni 2016 di Dinas Kesehatan Kota Surakarta dari 17 Puskesmas Surakarta pada tahun 2013 penderita asma sejumlah 2.112 penderita asma dan pada tahun 2014 ada 2.363 penderita asma sedangkan pada tahun 2015 jumlah anak yang menderita asma sejumlah 4.425 orang. Berdasarkan data Riskesdas di Jawa Tengah tahun 2018 asma berjumlah 91.161. Data Dinas Kesehatan Kabupaten Kebumen tahun 2016, ada pada urutan ke 3 penyakit yang tidak menular diantaranya ada Hipertensi berjumlah (7.231), DM (Diabetes Melitus berjumlah (1.585), Asma Bronkial (1.101). Sedangkan tahun 2018 asma meningkat menjadi 3.162.

Menurut Rhoades, 2011 dalam Santoso, Harnayetty, \& Bakar (2014) penyakit asma yang sering kambuh bisa ringan hingga berat. Pada proses inspirasi bisa terjadi akibat kontraksi yang minimal dari otot-otot pernapasan yang bisa mengakibatkan diafragma terdorong keatas, energy yang dikeluarkan sangat tinggi untuk mengangkat rongga dada serta adanya pengembangan paru yang minimal. Berdasarkan hal tersebut mengakibatkan oksigen yang masuk kedalam paru-paru hanya sedikit. Dalam proses ekspirasi, kontraksi pada pernafasan yang sedikit mengkibatkan saturasi oksigen mengalami penurunan. Shaffer, 2012 dalam
Samsuardi, 2012 Pasien asma pada saat serangan lebih sering menggunakan otototot interkostalis dari pada menggunakan otot-otot rektus abdominis. Diafragma merupakan otot pernapasan utama, dengan menggunakan otot-otot interkostalis secara terus-menerus, hal ini menyebabkan kelemahan terhadap otot pernapasan sehingga dibutuhkan terapi penguatan otototot pernapasan pada pasien asma. Salah satu intervensi pada pasien asma yang diterapkan untuk meningkatkan otot-otot pada system pernapasan untuk memaksimalkan ventilasi paru yaitu dengan Terapi Diafragmatic Breathing Exercise. Terapi pada pernapasan yang dilakukan dengan inspirasi melalui hidung, gerakan utamanya dengan abdomen, membatasi gerakan dada serta melakukan ekspirasi pernapasan melalui mulut merupakan terapi Diaphragmatic Breathing Exercise (Zega dalam Mayuni, 2015).

Menurut Widjanegara, Tirtayasa \& Pangkahilam (2015) Terapi Diaphragmatic Breathing Exercise adalah suatu terapi pada pernapasan pada penderita asma. Akibat dari terapi diaphragmatic breathing exercise yaitu mengakibatkan karbondioksida keluar dari dalam paru-paru, sehingga kerja pernapasan berkurang serta ventilasi mengalami peningkatan. Peningkatan ini akibat adanya peningkatan perfusi sehingga tekanan intraalveoli mengalami peningkatan serta pertukaran gas yang efektif. Terapi pernapasan dapat meningkatkan fungsi respirasi, bisa menurunkan respon yang berlebih dari jalan nafas. Menurut Suryantoro, Isworo, \& Upoyo, (2017) penatalaksanaan pada terapi ini untuk meningkatkan kebersihan jalan nafas, koping serta mencegah dari komplikasi. Menurut Putra, 2012 Dengan diberikan Terapi Diafragmatic Breathing Exercise otot-otot expirasi pada abdomen mengembang secara aktif sehingga memudahkan karbon dioksida keluar dari rongga thorax dan mengalami peningkatan pada ventilasi sehingga memperbaiki 
kinerja alveoli untuk mengefektifkan oksigen sehingga terjadi peningkatan terhadap saturasi oksigen. Terapi Diafragmatic Breathing Exercise bisa meningkatkan saturasi oksigen serta dapat meningkatkan efisiensi ventilasi dalam oksigen dengan peningkatan oksigen didalam aliran darah. Tujuan Terapi Diafragmatic Breathing Exercise agar pasien dengan masalah ventilasi dapat terkontrol dengan baik, serta bisa mengurangi kerja dalam system pernapasan. Terapi ini mampu menghilangkan kecemasan pada pasien Asma, meningkatkan relaksasi otot-otot pernapasan, mengurangi aktifitas otot pernapasan yang tidak terkoordinasi dengan baik, serta dapat mengurangi frekuensi pernapasan. Pernapasan Asma yang pelan dapat mengontrol kecemasan dan dapat merilekskan pasien yang terkena sesak nafas (Sepdianto dkk, 2013).

Pasien asma yang ada di Kecamatan Sruweng masih belum diajarkan mengenai terapi diaphragmatic breathing exercise. Dan terapi diaphragmatic breathing exercise masih belum dimasukan kedalam SOP (Standar Operasional Prosedur). Dan hasil wawancara dengan perawat mengenai terapi diaphragmatic breathing exercise, perawat sudah tau dengan terapi tersebut, namun belum menerapkan terapi tersebut kepasien asma. Pasien asma selalu beranggapan ketika banyak aktivitas seperti banyak gerak akan menimbulkan kekambuhan.

Berdasarkan observasi dan wawancara pada 3 pasien asma, pasien asma mengatakan belum mengetahui adanya terapi diaphragmatic breathing exercise, mereka hanya mengetahui apabila serangan asma kambuh mereka menggunakan inhaler. Dari hasil wawancara kepada pasien, pasien juga mengatakan gejala yang sering muncul, sesak napas, ada suara napas tambahan, dada juga terasa sakit.

Berdasarkan uraian diatas peneliti tertarik untuk melakukan penelitian Terapi diaphragmatic Breathing Exercise terhadap Pengontrolan Pernapasan Pasien Asma di Kecamatan Sruweng.

Tujuan penelitian ini yaitu Mengetahui pengaruh terapi diaphragmatic breathing exercise terhadap pengontrolan pernapasan pasien asma di Kecamatan Sruweng

\section{METODE PENELITIAN}

Penelitian ini menggunakan desain quasi experiment dengan pendekatan pretest-post-test with control two group design. Populasi dalam penelitian ini adalah 42 pasien asma. Sampel 32 pasien yang diambil secara accidental sampling. Data dianalisa secara deskriptif dan komparatif menggunakan uji $t$-test.

\section{HASIL PENELITIAN}

1. Karakteristik Pasien Asma

\begin{tabular}{clcc}
\hline Ket & Kategori & $\mathrm{F}$ & $\%$ \\
\hline Usia & $17-25$ tahun & 10 & 31,3 \\
& $26-35$ tahun & 2 & 6,3 \\
& $36-45$ tahun & 6 & 18,8 \\
& $46-55$ tahun & 7 & 21,9 \\
& $56-65$ tahun & 7 & 21,9 \\
\cline { 2 - 4 } Jenis Kelamin & Total & 32 & 100,0 \\
\hline \multirow{5}{*}{ Pendidikan } & Perempuan & 20 & 62,5 \\
& Laki-Laki & 12 & 37,5 \\
\cline { 2 - 4 } & Total & 32 & 100,0 \\
& SD & 18 & 56,3 \\
& SMP & 5 & 15,6 \\
& SMK & 9 & 28,1 \\
\cline { 2 - 4 } Pekerjaan & Total & 32 & 100,0 \\
& Petani & 5 & 15,6 \\
& IRT & 14 & 43,8 \\
& Pelajar & 5 & 15,6 \\
& Swasta & 8 & 25,0 \\
\cline { 2 - 4 } & Total & 32 & 100,0 \\
\hline
\end{tabular}

Berdasarkan tabel diatas menunjukkan sebagian besar pasien asma berusia kategori Masa remaja akhir usia 17 - 25 tahun $(31,3 \%)$, berjenis kelamin perempuan $(62,5 \%)$, pendidikan SD $(56,3 \%)$, pekerjaan ibu rumah tangga $(43,8 \%)$. 
2. Pengontrolan Pernapasan Pasien Asma Sebelum Perlakuan Terapi Diaphragmatic Breathing Exercise

\begin{tabular}{ccccc}
\hline Kategori & \multicolumn{4}{c}{ Pre Test } \\
\cline { 2 - 5 } & \multicolumn{2}{c}{$\begin{array}{c}\text { Kelompok } \\
\text { Intervensi }\end{array}$} & \multicolumn{2}{c}{$\begin{array}{c}\text { Kelompok } \\
\text { Kontrol }\end{array}$} \\
\cline { 2 - 5 } & $\mathrm{F}$ & $\%$ & $\mathrm{~F}$ & $\%$ \\
\hline $\begin{array}{c}\text { Tidak } \\
\text { Terkontrol } \\
\text { Terkontrol } \\
\text { Baik }\end{array}$ & 16 & 100,0 & 16 & 100,0 \\
$\begin{array}{c}\text { Terkontrol } \\
\text { Total }\end{array}$ & 0 & 0,0 & 0 & 0,0 \\
\hline Total & 16 & 100,0 & 16 & 100,0 \\
\hline Berdasarkan & tabel & diatas
\end{tabular}

menunjukkan sebelum diberikan perlakuan terapi Diaphragmatic Breathing Exercise seluruh responden pada kelompok memiliki pengontrolan pernapasan kategori tidak terkontrol yaitu 16 responden $(100,0 \%)$ sama halnya responden pada kelompok kontrol yang seluruhnya memiliki pengontrolan pernapasan kategori tidak terkontrol yaitu 16 responden $(100,0 \%)$

3. Pengontrolan Pernapasan Pasien Asma Setelah Perlakuan Terapi Diaphragmatic Breathing Exercise

\begin{tabular}{ccccc}
\hline Kategori & \multicolumn{4}{c}{ Post Test } \\
\cline { 2 - 5 } & \multicolumn{2}{c}{$\begin{array}{c}\text { Kelompok } \\
\text { Intervensi }\end{array}$} & \multicolumn{2}{c}{$\begin{array}{c}\text { Kelompok } \\
\text { Kontrol }\end{array}$} \\
\cline { 2 - 5 } & $\mathrm{F}$ & $\%$ & $\mathrm{~F}$ & $\%$ \\
\hline $\begin{array}{c}\text { Tidak } \\
\text { Terkontrol } \\
\text { Terkontrol } \\
\text { Baik }\end{array}$ & 0 & 0,0 & 10 & 62,5 \\
$\begin{array}{c}\text { Terkontrol } \\
\text { Total }\end{array}$ & 15 & 93,8 & 6 & 37,5 \\
\hline Total & 16 & 100,0 & 16 & 100,0 \\
\hline
\end{tabular}

Berdasarkan tabel diatas menunjukkan setelah diberikan perlakuan terapi Diaphragmatic Breathing Exercise sebagian besar responden pada kelompok perlakuan memiliki pengontrolan pernapasan kategori terkontrol baik sejumlah 15 responden (93,8\%), sedangkan responden pada kelompok kontrol sebagian besar respondennya memiliki pengontrol.an pernapasan kategori tidak terkontrol yaitu 10 responden $(62,5 \%)$.
4. Pengaruh Terapi Diaphragmatic Breathing Exercise Terhadap Pengontrolan Pernapasan Pasien Asma

a. Normalitas Data

\begin{tabular}{lcl}
\hline Data & $\mathrm{p}$ & Keterangan \\
\hline Pre ACT Perlakuan & 0,229 & Normal \\
Post ACT Perlakuan & 0,255 & Normal \\
Pre ACT Kontrol & 0,525 & Normal \\
Post ACT Kontrol & 0,164 & Normal \\
\hline
\end{tabular}

Berdasarkan tabel diatas menunjukkan hasil pengujian normalitas menggunakan uji Shapiro-Wilk diketahui bahwa signifikansi keempat data yang digunakan dalam penelitian ini memiliki signifikansi $>0,05$ sehingga data dinyatakan berdistribusi normal dan berlaku uji parametrik t-test.

b. Perbedaan Pengontrolan Pernapasan Pasien Asma Pada Kelompok Perlakuan

\begin{tabular}{cccc}
\hline $\begin{array}{c}\text { Pengontrolan } \\
\text { Pernapasan } \\
\text { Kelompok } \\
\text { Perlakuan }\end{array}$ & Mean & $\begin{array}{c}\text { Beda } \\
\text { Mea }\end{array}$ & $\mathrm{P}$ \\
& & $\mathrm{n}$ & \\
\hline Pre & 13,25 & 9,50 & 0,000 \\
Post & 22,75 & 0 & \\
& & &
\end{tabular}

Berdasarkan tabel diatas menunjukkan hasil uji statistik paired $t$ test, pada analisa sebelum diberikan obat asma dan Diaphragmatic Breathing Exercise rata-rata responden memiliki skor pengontrolan pernapasan 13,25 (tidak terkontrol) sedangkan analisa sesudah diberikan obat asma dan Diaphragmatic Breathing Exercise rata-rata responden memiliki skor pengontrolan pernapasan 22,75 (Terkontrol Baik). Peningkatan skor pengontrolan pernapasan sebelum dan sesudah perlakuan yaitu 9,500 dengan $p$ value: 0,000 . Oleh karena $\mathrm{p}$ value $(0,000<0,05)$ maka berarti ada perbedaan pengontrolan pernapasan pasien asma pada kelompok yang diberi perlakuan terapi 
Diaphragmatic Breathing Exercise di Kecamatan Sruweng.

c. Perbedaan Pengontrolan Pernapasan Pasien Asma Pada Kelompok Kontrol

\begin{tabular}{cccc}
\hline $\begin{array}{c}\text { Pengontrolan } \\
\text { Pernapasan } \\
\text { Kelompok Kontrol }\end{array}$ & Mean & $\begin{array}{c}\text { Beda } \\
\text { Mean }\end{array}$ & $\mathrm{P}$ \\
\cline { 1 - 2 } Pre & 13,25 & 6,000 & 0,000 \\
\cline { 1 - 2 } Post & 19,25 & & \\
\hline
\end{tabular}

Berdasarkan tabel diatas menunjukkan hasil uji statistik paired $t$ test, pada analisa sebelum diberikan obat asma dan terapi nafas dalam rata-rata responden memiliki skor pengontrolan pernapasan 13,25 (tidak terkontrol) sedangkan analisa sesudah diberikan obat asma dan terapi nafas dalam rata-rata responden memiliki skor pengontrolan pernapasan 19,25 (Tidak Terkontrol). Peningkatan skor pengontrolan pernapasan sebelum dan sesudah perlakuan yaitu 6 dengan $p$ value: 0,000 . Oleh karena $p$ value $(0,000<0,05)$ maka berarti ada perbedaan pengontrolan pernapasan pasien asma pada kelompok yang diberi obat asma dan terapi nafas dalam di Kecamatan Sruweng.
d. Pengaruh

$$
\text { Terapi Diaphragmatic }
$$
Breathing
Exercise
Terhadap
Pengontrolan Pernapasan Pasien Asma

\begin{tabular}{lcccc}
\hline & Kelompok & Mean & $\begin{array}{r}\text { Beda } \\
\text { Mean }\end{array}$ & P \\
\hline $\begin{array}{l}\text { Peningkat } \\
\text { an skor }\end{array}$ & Perlakuan & 9,50 & 3,500 & 0,000 \\
ACT & & & & \\
\hline \multicolumn{2}{c}{ Berdasarkan } & & & \\
\hline
\end{tabular}

menunjukkan bahwa rata-rata peningkatan skor pengontrolan pernapasan kelompok perlakuan yaitu 9,50 sedangkan rata-rata peningkatan skor pengontrolan pernapasan kelompok kontrol yaitu 6,000. Perbedaan skor antara kelompok perlakuan dan kelompok kontrol yaitu 3,500 dengan $\mathrm{p}$ value: 0,000 ( $\mathrm{p}<0.05)$ yang berarti ada pengaruh terapi diaphragmatic breathing exercise terhadap pengontrolan pernapasan pasien asma di Kecamatan Sruweng.

\section{PEMBAHASAN}

Ditinjau dari karakteristik usia pasien asma, sebagian besar berusia 17 25 tahun (31,3\%) karena pada usia tersebut pasien asma dapat menderita asma sejak masa anak atau remaja yang berlangsung terus atau timbul setelah periode remisi tetapi dapat juga terjadi pada dewasa tua atau lebih dari 65 tahun. Adanya perubahan hormonal yang terjadi pada masa dewasa memberikan kontribusi terhadap perkembangan asma (Postma, 2017).

Menurut asumsi peneliti dari karakteristik jenis kelamin, sebagian besar berjenis kelamin perempuan (62,5\%). Berbagai sumber kepustakaan mengatakan bahwa penyebab prevalensi asma yang tinggi pada perempuan, masih belum dapat dipastikan karena berhubungan dengan multifaktorial. Perempuan dikatakan lebih rentan terhadap pajanan yang dapat memicu reaksi hipersensitifitas, dan merespon reaksi dengan lebih buruk dibandingkan pada laki-laki. Faktor aktivitas dan stress psikologis juga berperan dalam perburukan dan angka kekambuhan asma bronkial, dimana lebih rentan pada kaum perempuan. Terlebih karakteristik berjenis kelamin perempuan lebih mengutamakan perasaan dari pada soal logika sehingga pada perempuan stress psikologis akan mudah menghampiri dan lebih rentan terhadap asma.

Ditinjau pada penelitian ini dari karakteristik pendidikan, sebagian besar responden berpendidikan SD (56,3\%). Menurut asumsi peneliti sebagian besar pada penelitian ini adalah responden yang memiliki pendidikan rendah. Dimana responden kurang akan pengetahuan tentang kesehatan dirinya, dan menganggap kondisinya baik-baik saja tanpa khawatir kondisinya akan semakin parah. Kondisi yang semakin parahpun responden masih ada saja yang tidak mau berobat. Pengetahuan yang kurang akan mempengaruhi kesehatan yang dialaminya dan akan lebih beresiko dibandingkan 
dengan seseorang yang berpendidikann atau berpengetahuan.

Menurut asumsi peneliti ditinjau dari karakteristik pekerjaan, sebagian besar responden memiliki pekerjaan sebagai ibu rumah tangga (43,8\%). Angka kejadian asma yang tinggi pada ibu rumah tangga yang didapatkan dari hasil penelitian ini diduga memiliki hubungan dengan alergen indoor sebagai salah satu faktor pencetus asma. Ibu rumah tangga memiliki resiko yaitu terpapar dengan debu tungau rumah ketika sedang aktivitasnya membersihkan ruangan didalam rumah. Faktor pencetus asma salah satunya adalah masuknya suatu alergen ke dalam saluran pernapasan seseorang sehingga merangsang terjadinya reaksi hipersensitivitas tipe 1 .

Hasil penelitian menunjukkan sebelum diberikan obat asma dan Diaphragmatic Breathing Exercise ratarata responden memiliki skor pengontrolan pernapasan 13,25 (tidak terkontrol). Hasil evaluasi kuesioner pada kelompok intervensi menunjukkan sebagian besar pasien kadang-kadang mengalami hambatan dalam mengerjakan pekerjaan sehari-hari sejumlah 9 responden $(56,3 \%)$, kadang-kadang mengalami sesak napas sejumlah 11 responden $(68,8 \%)$, kadangkadang mengalami gejela asma sejumlah 7 responden (43,8\%) kadang-kadang menggunakan obat semprot sejumlah 6 responden $(37,5 \%)$, dan sering menilai tingkat kontrol asma sejumlah 9 responden $(56,3 \%)$.

Sedangkan hasil evaluasi kuesioner pada kelompok kontrol menunjukkan sebagian besar pasien kadang-kadang mengalami hambatan dalam mengerjakan pekerjaan sehari-hari sejumlah 8 responden $\quad(50,0 \%)$, kadang-kadang mengalami sesak napas sejumlah 11 responden $(68,8 \%)$, kadang-kadang mengalami gejela asma sejumlah 9 responden $(56,3 \%)$, kadang-kadang menggunakan obat semprot sejumlah 6 responden $(37,5 \%)$, dan sering menilai tingkat kontrol asma sejumlah 8 responden $(50,0 \%)$.
Ada bebrapa yang menyebabkan asma bronkial mengalami kekambuhan yaitu bisa disebabkan oleh beberapa antigen diantaranya banyak debu, keadaan rumah yang kotor, banyak hewan peliharaan seperti kucing, kecoa dan lainnya. Kondisi stress yang berlebihan pada perempuan juga menjadi faktor penyebabnya, serta adanya riwayat hipersensitivitas yang dapat menjadi penyebab kekambuhan asma bronkial. Pada pasien asma bronkial harus rajin melakukan pengontrolan asma secara optimal, asma banyak menyebabkan masalah dalam kesehariannya, kerusakan pada paru, serta mengalami komplikasi berat terhadap penderita asma. maka dari itu penanganan asma menjadi cara yang baik (Crocker, et al, 2011).

Hasil penelitian menunjukkan sesudah diberikan obat asma dan Diaphragmatic Breathing Exercise ratarata responden memiliki skor pengontrolan pernapasan pernapasan 22,75 (Terkontrol Baik). Hasil evaluasi kuesioner pada kelompok intervensi menunjukkan sebagian besar pasien jarang mengalami hambatan dalam mengerjakan pekerjaan sehari-hari sejumlah 9 responden $(56,3 \%)$, tidak pernah mengalami sesak napas sejumlah 15 responden $(93,8 \%)$, tidak pernah mengalami gejela asma sejumlah 13 responden $(81,3 \%)$, tidak pernah menggunakan obat semprot sejumlah 9 responden $(56,3 \%)$, dan tidak pernah menilai tingkat kontrol asma sejumlah 10 responden $(62,5 \%)$.

$$
\text { Pada kelompok kontrol }
$$
menunjukkan sesudah diberikan obat asma dan terapi nafas dalam rata-rata responden memiliki skor pengontrolan pernapasan masih dalam kondisi tidak terkontrol skor 19,25. hasil evaluasi kuesioner pada kelompok kontrol menunjukkan sebagian besar pasien jarang mengalami hambatan dalam mengerjakan pekerjaan sehari-hari sejumlah 13 responden $(81,3 \%)$, jarang mengalami sesak napas sejumlah 14 responden $(87,5 \%)$, jarang mengalami gejela asma 
sejumlah 12 responden $(75,0 \%)$, jarang menggunakan obat semprot sejumlah 13 responden $(81,3 \%)$, dan jarang menilai tingkat kontrol asma sejumlah 12 responden $(75,0 \%)$.

$$
\text { Menurut peneliti Terapi }
$$

Diaphragmatic Breathing Exercise dapat memberikan manfaat yang lebih besar, aman, nyaman dan memperbaiki kualitas hidup seluruh penderita asma karena karena terapi ini merupakan suatu bentuk olahraga yang gerakannya tidak begitu berat (relaks), tidak menyebabkan energi banyak berkurang. Terapi ini merupakan olahraga yang intensitas dan frekuensinya tepat bagi penderita asma sehingga dengan melakukan terapi ini diharapakan dapat bermanfaat mengendalikan dan mengurangi kambuhnya serangan asma.

Melatih otot-otot pernafasan dapat meningkatkan fungsi otot respirasi, mengurangi beratnya gangguan pernafasan, meningkatkan toleransi terhadap aktivitas. Dan menurunkan gejala dispnea. Diaphragmatic Breathing Exercise merupakan latihan pernafasan yang merelaksasikan otot-otot pernafasan saat melakukan inspirasi dalam. Pasien berkonsentrasi pada upaya mengembangkan diafragma selama melakukan inspirasi terkontrol (Potter\& Perry, 2016).

Pernafasan diafragma yang dilakukan berulang kali dengan rutin dapat membantu seseorang menggunakan diafragmanya secara benar ketika dia bernafas. Teknik ini berguna untuk menguatkan diafragma, menurunkan kerja pernafasan, melalui penurunan laju pernafasan, menggunakan sedikit usaha dan energi untuk bernafas, dengan pernafasan diafragma maka akan terjadi peningkatan volume tidal, penurunan kapasitas residu fungsional, dan peningkatan pengambilan oksigen yang optimal (Smith, 2014). Setelah melakukan Diaphragmatic Breathing Exercise diharapkan pasien dapat mengkondisikan dirinya saat merasa akan terjadi serangan ataupun saat serangan asma, dengan begitu diharapkan keluhan pasien menjadi minimal dan kualitas hidup pasien asma pun dapat meningkat.

Hasil penelitian menunjukkan ada pengaruh terapi diaphragmatic breathing exercise terhadap pengontrolan pernapasan pasien asma di Kecamatan Sruweng. $p$ value: 0,000 ( $\mathrm{p}<0.05)$. Latihan pernapasan sangat berperan dalam mengembalikan fungsi pernapasan pasien pada pasien asma yang sebelumnya mengalami hiperventilasi dan menyebabkan kekurangan $\mathrm{CO} 2$ sehingga tubuh menyesuaikan diri dengan menurunkan kadar oksigen di jaringan, hal ini yang menyebabkan terjadinya penurunan saturasi oksigen perifer. Menurut penelitian Yamaguti, et al, (2012), terapi diaphragmatic breathing exercise lebih berfokus bernapas menggunakan otot-otot pada diafragmanya dibandingkan dengan menggunakan otot-otot aksesoris sehingga dapat menurunkan pernapasan yang lebih maksimal serta dapat menurunkan frekuensi dalam sistem pernapasan.

Didukung oleh penelitian Black \& Hawks, (2014), diafragma adalah otot yang paling utama dalam pernapasan yang mempunyai peran dibawah thorak yang melekat pada prosesus xifoideus sternum dan usuk pada bagian bawah. Kontraksi pada otot diafragma dapat menarik otot kebawah sehingga dapat meningkatkan ruang thorak secara luas dan pengembangan paru secara aktif. Menurut (Smith, 2004 dalam Mayuni et al, 2015), teknik pernapasan diafragma berguna untuk menguatkan diafragma selama pernapasan, menurunkan kerja pernapasan, menggunakan sedikit usaha dan energi untuk bernafas, dengan pernapasan diafragma akan terjadi peningkatan volume tidal, penurunan kapasitas residu fungsional dan peningkatan pengambilan oksigen yang optimal (Smith, 2004 dalam Mayuni et al, 2015).

Latihan pernapasan dapat meningkatkan pengembangan paru sehingga ventilasi alveoli meningkat dan akan meningkatkan konsentrasi oksigen 
dalam darah sehingga kebutuhan oksigen terpenuhi (Smeltzer \& Bare, 2012). Sesuai dengan teori di atas terlihat bahwa hasil penelitian menunjukan peningkatan signifikan nilai skor pengontrolan pernapasan sebelum dan sesudah perlakuan yaitu 10,571 yang sebelumnya 13,25 (tidak terkontrol) sedangkan analisa sesudah diberikan obat asma dan Diaphragmatic Breathing menjadi 22,75 (Terkontrol Baik).

Pengaruh ini terjadi karena pemberian latihan pernafasan diafragma melatih otot- otot utama pernafasan yaitu otot-otot diafragma yang bekerja pada saat inspirasi dan otot-otot abdomen yang bekerja pada saat ekspirasi. Pada saat terjadinya proses pernafasan otot-otot pernafasan merupakan komponen terpenting dari pompa respirator dan harus berfungsi dengan baik untuk menghasilkan ventilasi yang lebih efektif (Ariestianti, dkk .2013).

Dalam berbagai tulisan beberapa ahli, latihan pernafasan diafragma yaitu Diaphragmatic Breathing Exercise yaitu melatih pasien untuk menggunakan diafragma dengan baik dan merelaksasikan otot-otot aksesoaris (otot bantu pernafasan), dan bertujuan meningkatkan volume alur napas, menurunkan residu fungsional, memperbaiki ventilasi dan memobilisasi sekresi mukus pada saat drainase postural (Semara, 2012). Biasanya penderita asma memiliki pola pernafasan yang salah dan cenderung menggunakan pernafasan dada atas dan mengempiskan perut pada saat inspirasi. Pada saat kondisi ini energi yang diperlukan tinggi sedangkan pengembangan paru minimal, karena diafragma yang terdorong keatas akibat perut yang dikempiskan. Pada saat ekspirasi, perut mengembang dan diafragma terdorong ke bawah sehingga menyebabkan sukar melakukan ekspirasi (Herman, 2017). Dengan diberikan latihan pernafasan diafragma terjadi pengembangan rongga thorax dan paru saat inspirasi serta otot-otot ekspirasi (otot- otot abdomen) berkontraksi secara aktif sehingga mempermudah pengeluaran udara (CO2) dari rongga thorax kemudian mengurangi kerja bernafas dan peningkatan ventilasi sehingga terjadi peningkatan perfusi juga perbaikan kinerja alveoli untuk megefektifkan pertukaran gas sehingga kadar $\mathrm{CO} 2$ dalam arteri berkurang maka dengan latihan pernafasan diafragmatik saturasi oksigen meningkat (Semara, 2012).

\section{DAFTAR PUSTAKA}

Ariestianti, I., Pangkahila, J. A., \& Purnawati, S. (2013). Pembeerian diapragmatic breathing sama baik dengan pursed lips breathing dalam meningkatkan arus puncak ekspirasi pada perokok aktif anggota club motor Yamaha vixion Bali di Denpasar. Majalah Ilmiah Fisioterapi Indonesia. 1 (1). http://ojs.unud.ac.id/index.php/ mifi/article/view/8473/6317

Black, J. M. \& Hawks, J.H. (2014).Medical surgical nursing: Clinical management for positive outcomes. (8 th ed). Singapore: Elsevier.

Crocker, Et Al. (2011). Effectiveness Of Home-Based, Multi-Trigger, Multicomponent Interventions With An Environmental Focus For Reducing Asthma A Community Guide Systematic Review. Ev Med 201141 (2s1):S5-S32) Published By Elsevier Inc. On Behalf Of American Journal Of Preventive Medicine.

Dinkes, Jateng. (2013). Profil Kesehatan Provinsi Jawa Tengah. Semarang: Dinkes Jateng.

Dinas Kesehatan Surakarta. (2015). Profil Kesehatan Surakarta. Surakarta: Dinas Kesehatan Surakarta. 
Depkes. (2018). Riset Kesehatan Dasar (Riskesd). Jakarta: EGC.

Herman. (2017). Pengaruh Latihan Terhadap Fungsi Otot Dan Pernapasan. ILARA, I.

Kementrian Kesehatan Republik Indonesia. (2014). Propil Kesehatan Indones Jakarta. Pusat Data dan Informasi Kementrian Kesehatan RI. http://www.depkes.go.id/resourc es/download/pusdatin/profilkesehatan/profil-kesehatanindonesia.2014.pdfia

Kementrian Kesehatan Republik Indonesia. (2018). Riset Kesehatan Dasar; RISKESDAS. Jakarta: Balitbang Kemenkes RI. Diakses pada Desember 2019

Mayuni, et al. (2015). Pengaruh Diaphragmatic Breathing Exercise Terhadap Kapasitas Vital Paru Pada Pasien Asma Di Wilayah Kerja Puskesmas III Denpasar Utara. Coping Ners Jurnal, 1-6.

Postma DS. (2017). Gender differences in asthma development and progression. Gender Medicine Journal hal 133-146.

Potter, P., Perry, A., Stockert, P., \& Hall, A. (2016). Fundamentals of Nursing $\left(9^{\text {th }}\right.$ ed). St. Louis: Elsevier/Mosby

Samsuardi. (2015). Manfaat Latihan Penguatan Otot-Otot Pernapasan Terhadap Peningkatan Kapasitas Vital Paru Pada Penderita Asma.

Semara, Juniartha Putra. (2012). Pengaruh Latihan Nafas Diafragma Terhadap Fungsi Pernapasan Pada Pasien Penyakit Paru Obstruksi Kronik. Denpasar: Poltekkes Kemenkes.

Shaffer, T., Wolfsoon, M, \& Bhutan, V. (2012). Respiratory Muscle Function Assesment And Training United States of America: Physical therapy journal of the American physical therapy association.

Santoso, F. M., Harmayetty, H., \& Bakar, A. (2014). Perbandingan Latihan Napas buteyo dan upper body exercise terhadap arus puncak ekspirasi pada pasien dengan asma bronkial. Critical, Medical, \& surgical Nursing Journal, 1-8.

Sepdianto, dkk. (2013). Peningkatan Saturasi Oksigen Melalui Latihan Diaphragmatic Breathing Pada Pasien Gagal Jantung. Malang: Poltekes Kemenkes.

Smeltzer, \&, B. (2010). Texbook of Medical-Surgical Nursing Vol 2. Philadelphia: Linppincott William \& Wilknis.

Smith, J., F. (2014). Chest physical therapy. Wausau: The Thompson corporation. http://www.chclibrary.org/micro ed/00042330.html

Suryantoro, E, Isworo, A, \& Upoyo, A.s. (2017). Perbedaan Efektivitas Pursed Lips Breathing Dengan Six Minutes Walk Test Terhadap Forced Expiratory. Jurnal Keperawatan Padjadjaran. 5 (2).

Sugiyono. (2009). Metode Penelitian Kuantitatif, Kualitatif, dan $R$ \& $D$. Bandung: Alfabeta.

(2011). Statistika untuk

Penelitian. Bandung. Alfabeta..

Susanto, M. \& Ardiyanto, T., (2015). Pengaruh Terapi Nafas Dalam Terhadap Perubahan Saturasi Oksigen Perifer pada Pasien di Rumah Sakit Wilayah Kabupaten Pekalongan. Diaskses pada tanggal 13 Juni 2020 Pukul 20.00 WIB http://www.eskripsi.stikesmuhpkj.ac.id/eskripsi/index.php?p=f $\underline{\text { stream } \& \text { fid }=873 \& \text { bid }=935}$ 